\title{
Toward a Sustainable Campus: Comparison of the Physical Development Planning of Research University Campuses in Malaysia
}

\author{
Mohd Zulhanif Abd Razak (Corresponding author) \\ Department of Architecture, Universiti Kebangsaan Malaysia \\ 43600 UKM Bangi, Selangor, Malaysia \\ Tel: 60-12-508-3697_E-mail: wetblanket9287@yahoo.com \\ Nur Akmal Goh Abdullah \\ Department of Architecture, Universiti Kebangsaan Malaysia \\ 43600 UKM Bangi, Selangor, Malaysia \\ Tel: 60-19-346-8399 E-mail: akgoth@vlsi.eng.ukm.my \\ Muhammad Farihan Irfan Mohd Nor \\ Department of Architecture, Universiti Kebangsaan Malaysia \\ 43600 UKM Bangi, Selangor, Malaysia \\ Tel: 60-12-374-7066 E-mail: irfan@vlsi.eng.ukm.my \\ Ismar M.S. Usman \\ Department of Architecture, Universiti Kebangsaan Malaysia \\ 43600 UKM Bangi, Selangor, Malaysia \\ Tel: 60-19-651-3910 E-mail: imscarch@gmail.com \\ Adi Irfan Che-Ani \\ Department of Architecture, Universiti Kebangsaan Malaysia \\ 43600 UKM Bangi, Selangor, Malaysia \\ Tel: 60-19-203-3551 E-mail: adiirfan@vlsi.eng.ukm.my
}

Received: January 10, 2011

Accepted: July 7, 2011

doi:10.5539/jsd.v4n4p210

\begin{abstract}
Physical development planning is a powerful tool for determining and shaping the living environment of any area, including on campus. If the growing social concern with sustainability is to be addressed by physical planning initiatives, the effectiveness of such initiatives must be assessed soon. The objective of this research is to study the effectiveness of the physical development planning of four research university campuses in Malaysia. These universities have undergone changes to enhance their sustainability. The scope of this research is limited to the physical planning of the campus. Four research universities have been chosen: National University of Malaysia (UKM), University Sains Malaysia(USM), University of Malaya (UM) and University Putra Malaysia (UPM). The research methods used consisted of a questionnaire, behavioral observations and a visual study. A total of 400 respondents were included and were divided equally among the campuses. The resulting data were statistically analyzed. The results from each campus were compared. The results obtained by questionnaire were cross-referenced with the findings obtained from other techniques (behavioral observation and visual study) to obtain a detailed explanation. The research found that many similar problems in physical development planning have arisen on each campus. However, the extent and severity of the problems vary based on the individual approach taken toward physical development planning. The results show that the most compact campus, USM has the fewest problems when compared to the other campuses. This finding supports previous research and indicates that a compact campus tends to create a sustainable pattern of life on campus.
\end{abstract}

Keywords: Sustainable, Campus, Physical development, Planning, Malaysia

\section{Introduction}

The term university campus refers to an institutional space that is designed for use in the education and residence of college students (Isiaka \& Siong 2008) and includes the building and other physical elements found in the associated area (Shuhana et al. 2007b). The establishment of the university campus usually occurs in stages 
according to its current needs for growth and development (Walker \& McGough 1962). Existing university campuses require further development from time to time, based on the objectives that must be achieved. The physical development planning of a campus can be considered to be successful if the project goals are achieved.

Since the Earth Summit sessions in 1992 and 2002, the issue of sustainability has become a critical topic of discussion (Abdul Ghani \& Aziah 2007). Because they are a center of knowledge, universities around the world have become increasingly concerned with this issue (Beringer et al. 2009). Accordingly, many universities have begun to promote strategies for creating sustainable campuses through education and design projects (Davis \& Wolksi 2009).

Universities in Malaysia expressed a commitment to implement sustainable practices when only a few universities were moving toward creating a sustainable campus. However, there are several weak aspects in campus physical development planning that have resulted in the failure to create an environment that offers a conducive environment for learning and living (Shuhana et al. 2007a). In addition, campus physical development planning in Malaysia is less sensitive to change and does not satisfy the needs of students on campus, even though they are the primary 'clients' in campus (Mohd Tajuddin 2003).

In the scope of this research, a sustainable campus is defined as a campus characterized by operations, social and economic, which promote the long term survival of the environment and our own social structures. The purpose of this research was to examine existing campus physical development plans and their impact on campus life, especially for students.

\section{Understanding a Sustainable Campus}

The implementation of sustainable development remains a major challenge today, despite the worldwide acceptance of the importance of sustainability issues (Farrell \& Hart 1998). Sustainable development (SD) has various interpretations, depending on the field of endeavor (Lele 2004). According to the Bruntland Report (1987), SD refers to development that "meets the needs of the present without compromising the ability of future generations to meet their own needs", which has since been the general and basic interpretation. Most people have interpreted SD as environmental development only; however, SD has sometimes been interpreted as "'sustained growth", "sustained change", or simply "successful" development (Lele 2004). In addition, SD should emphasize all of the primary aspects of life, including social, ecological and economic qualities (Sohif et al. 2009).

"The ... campus is a world in itself, a temporary paradise, a pleasant stage in life."- Le Corbusier, 1936.

The statements above encourages the creation of a comfortable and pleasant campus or, in other words, a sustainable campus. Universities are centers of innovation and idea development and are the perfect place to cultivate ideas for sustainability. In addition, they are able to create public awareness of how sustainability can be integrated into everyday life (Jain \& Pant 2010). They are poised to be models for their communities and demonstrate the implementation of sustainability policies on their campuses (Nicolaides 2006; Ferrer-Balas et al. 2008). Hence, many universities have implemented 'green campus' development projects as a response to calls for sustainable development (Isiaka \& Siong 2008).

The establishment of sustainable practices on campus and the demonstration of better management of practices that comply with sustainability rules, give higher education institutions the opportunity to use their campuses to educate the community at large about progressive models of development (Franklin et al. 2003). In addition, a sustainable campus also provides an environment that can enhance formal learning with the aesthetic component common to sustainable designs (Campos, 2008). According to Norton et al. (2007), campus planning effects the entire campus in terms of environmental, social and economic development and thus should focus on the university's mission and its implications when planning and building the physical characteristics of a campus, especially in terms of land allocation and incorporation, locations of academic and residential areas and provision of commercial facilities.

A campus can also be considered a city consisting of elements that are highly interdependent. According to Dober (1963), there are three main parts of a campus, which include the buildings, outdoor spaces and support elements such as utilities and circulation systems. He added that utility and circulation systems are necessary elements that support the activities of the institution. Dober (1963) also stated that a campus has to be aware of this interdependency while planning, which means that no system can be planned independently from its surroundings. In addition, the gradual development of the campus will result in different types of building shapes because each is planned and constructed by different groups (Walker and McGough 1962).

Without a long term plan for an ideal campus physical structure, evolutions in growth patterns will inhibit the development of the campus as a whole (D'Amico and Brooks 1968). Walker and McGough (1962) suggested that the appearance of each building must be developed based on elements of the existing buildings on campus, but this does not mean it should be exactly same as the existing buildings; instead, there should be a balance of featured elements so that a unity is maintained throughout the entire campus architecture. This statement was also supported by Shuhana et al. (2007a) when they suggested that planning should take into account aspects of unity in designing the buildings and their surroundings, while maintaining a necessary diversity of design to 
highlight areas that offer accommodations for varying disciplines, activities, and microcultures on campus. Thus, diversity can be achieved through a balance of consistent and unique elements, which will help strengthen the campus structure to be clearly and simply characterized (Shuhana et al. 2007a).

In 1968, D'Amico and Brooks state that the developments of most campuses have been accomplished by simple accretion. This is usually achieved by placing new buildings in empty spaces without evaluating the surrounding functional relationships. In addition, various adverse effects could be created, such as barriers to students' movement, congested network circulation, and issues with parking spaces. Thus, current action will impact future events, regardless of whether or not the effects are positive.

One of the challenges of sustainable development is to develop buildings within the existing campus area, apart from the new green areas (Wheeler 2002). Wheeler has proposed 'infill' development, which refers to the development that occurs within the currently existing areas. According to Wheeler, this concept will minimize the use of vehicles and services. However, people can use the existing facilities and avoid expansion into new areas. Drumheller et al. (2001) also support that it is better to develop the existing areas (infill) than to develop new areas to reduce new loads on the transportation systems. The distance between destinations will become shorter and driving needs will be reduced.

Previous studies have proven that compact development planning is able to encourage sustainability. Compact development planning not only provides advantages in terms of the environment but also promotes the creation of a healthy social life and reduces economic problems. Burton (2000) stated the following seven advantages of compact development:

i. $\quad$ Reduced land usage;

ii. $\quad$ Reduced vehicle dependency;

iii. Reduced usage of resource and emission of pollution;

iv. Encouragement of public transportation, walking and cycling;

v. Better access to facilities and services;

vi. Efficient provision of infrastructure and utilities; and

vii. Redevelopment of existing areas.

A principle called 'total environment' could potentially provide a sustainable campus life as described above (Burns 2001). This principle refers to the implementation of a space allocation system wherein usage is multi-functional. It describes the creation of an area that contains residential, academic, business, facilities and social functionality in the same space. Thus, a livable community can be achieved in which movement distance and cost can be reduced and natural surveillance can be increased.

\section{Research Method}

This paper offers statistical data on a recent study of four university campuses in Malaysia to examine the students' perception of their campuses' physical condition. A total of 400 questionnaires were used in this study. Each campus was canvassed with 100 questionnaires. The number of questionnaires selected was based on de Vaus (2002) to achieve a result within the $95 \%$ confidence interval. Additionally, Hoinville et al. (1977) stated that the minimum sample size for any subgroup must be $50-100$ cases.

The questionnaires were distributed among the students who live on the campuses. Students are considered 'clients' and are encouraged to criticize the activities of the campus and allowed to demand reform on environmental issues and sustainability (Dahle \& Newmayer 2001; Nicolaides 2006). Feedback from target groups is essential to ensure that their needs are taken into account in the planning stages; this process is known as community participation (Nurwati et al. 2006). According to Sulong Mohamad (1983), it is important for a development plan to meet the requirements, ambitions or aspirations of the affected society. He added that a development plan that cannot meet the requirements of the affected society is a futile effort.

The questions were aimed at understanding how students experience their campuses, their opinion about the campus, and their expectations for the campus. To obtain results that represent the entire campus, the questionnaires were given in each residential college, where the numbers of respondents for each residential college are equal. The data obtained were statistically analyzed using Microsoft Excel and presented in tables.

In addition, a visual study and behavioral observations were applied in this study to obtain additional information. The visual study gathered information about the form, composition and appearance of the campus (Shuhana et. al. 2007b). While data collected by a behavioral observation method described the physical condition, interactions and the general atmosphere of the campus (Chua 2006).

This information will help explain the physical condition of the campuses in concert with explanations of the responses given by the students. These techniques were implemented by collecting images of the campus' environment, making observations of campus life and studying the campus layout. Comparisons among the campuses were conducted once the overall results for each campus were obtained.

\section{Finding: Comparative Study between Four Universities}

This research found that different approaches have been used to plan the physical development of each campus. 
Research also found that each approach has its own advantages and disadvantages. However, there are common problems shared between all of the research campuses.

\subsection{Structural layout of the campus.}

This research found that the four campuses were planned using different approaches; the structural layout of the campus affects the pattern of life on campus, especially in terms of accessibility and circulation. Additionally, it appears that the physical development of these campuses is only minimally concerned with the relationship between the functional areas and buildings on campus. The figures at the end of this paper show the distribution of the areas where development of the campuses was planned.

Structures of the internal layout of the UKM campus are divided into three (3) areas (i.e., the Range 1, Range 2 and Range 3). The Range 1 area is planned using the concept of 'core centralization' in which the academic areas are placed in the center and surrounded by the social areas and hostels. Development of the campuses in Range 2 and Range 3 appears to be by simple accretion; new buildings are placed in available spaces without assessing the functional relationship of the buildings (Figure 1).

The USM main campus has been planned to be more compact when compared to the other campuses. This may be due to the limited supply of land for the campus because it is already surrounded by developed areas. The facilities area is located at the center and surrounded by academic areas, while residential areas are located in the suburban campus. The position of the buildings, especially the facilities and academic areas, are close to each other (Figure 2).

UM campus planning is scattered; some academic areas are located far from the main academic areas. The UM campus layout resembles a 'centralized core' structure, with the residential area surrounding the social and academic areas. However, the 'centralized core' is quite broad and not well organized, and there is an area in the center of campus that has not been developed. Hilly terrain factors may be barriers to developing that area and creating a well-organized structure (Figure 3).

The UPM main campus is the largest campus in the study. Campus planning has been divided into two main areas, academic and residential areas. Academic buildings have been grouped into one area, and residential areas are also grouped in the same manner. The administration and student facilities are grouped together in the academic areas. There are residential houses, fields, sporting courts and fitness centers in the residential areas (Figure 4).

\subsection{Accessibility}

Accessibility is defined as the ability to obtain goods and access to services and activities (Litman 2008). The feedback obtained from the survey found that the accessibility to academic areas from residential areas is highest for the USM campus (65\%), followed by UPM (63\%), UM (59\%) and UKM (50\%) campuses (Refer to Table 1). This may be due to the compact layout of the campus, which reduced the distance between residential areas and academic areas. For the UKM campus, the random placement of students and campus-wide growth using simple accretion causes the distance between residential areas and the academic areas to increase.

Accessibility to the facilities area is highest at the UKM campus (61\%) and lowest at the UM campus (39\%) (Refer to Table 1). These results may be influenced by the centralized location of the facilities on the UKM campus. The continuity of covered walkways and the placement of most of the residential colleges around the building complex also influenced the results. As for the UM campus, the position of the facilities area is located in the center of campus. However, the distance of the buildings is quite far from residential areas, and there is no covered walkway connecting the buildings to residential areas.

USM and UPM campuses recorded the highest results $(62 \%)$ in terms of accessibility to the recreational areas, followed by UM (515) and UKM (34\%) campuses (Refer to Table 1). The USM and UPM campuses provide recreational areas that are not focused in only one area. Although the main recreational area is far from some residential areas, the campus provides a sport field in most of the residential areas. Thus, it is easier for the students to exercise. As for the UKM campus, the position of the recreational and sports area is far from most of the residential areas because it is located on the suburban side of the campus. Meanwhile, most of the residential areas do not offer facilities for the purpose of recreation.

Continuity of the network of roads and paths allows for easier travel (Litman 2008). This research has found that there were similarities in the aspect of circulation on the research campuses. The results show that the majority of respondents said that there is no continuity of covered walkways on their campus (Refer to Table 2). When compared to UKM students' responses, the majority of students at other campuses found walking on campus to be relatively comfortable, (29\%) (Refer to Table 2). All of the research campuses have shown a strong expression of dissatisfaction with the availability of bike lanes on their campus (Refer to Table 2).

Research has found that all research campuses place less emphasis on pedestrian comfort. Pedestrian circulation on these campuses is not designed well; there was only a sidewalk alongside the road without covered walkways. Walkways should be designed separately from vehicle circulation (Sulong Mohamad 1983) to ensure pedestrian safety and should be covered to provide comfort to the users (Aldrin et al. 2006). Pedestrian walkways should be 
the backbone of the campus because they act as a liaison to the main areas on campus (UVic Campus Planning Committee, 2005).

Besides walking, bicycles are also a sustainable transportation mode (Drumheeler et al. 2001, Beatley 2003) because they do not pollute the air and have a minimal carbon footprint; bicycles are even known to improve the health of the cyclist (Drumheller et al. 2001). Research has found that special lanes for cyclist are not adequately provided on research campuses. Bicycle lanes are usually shared with pedestrian walkways or vehicle lanes. This situation can be dangerous both to pedestrians and cyclists. Similar to the case of pedestrian, one way to encourage students to use bicycles is by providing comfortable and safe facilities to support their use. Beatley (2003) states the use of bicycles can be improved by separating the bicycle lane from the vehicle lane and by providing a proper place for parking bicycles and bicycle specific signs and markings.

\subsection{Building Design}

Planning should consider aspects of unity across campus, while maintaining the diversity necessary to support the various disciplinary areas and microcultures that exist on campus (Shuhana et al. 2007a). The majority of respondents from the USM, UM and UPM campuses stated that the building designs on their campus are each unique and show their own identity (Refer to Table 3). However, the majority of UKM respondents believed that the building design of their campus is not unique, and each failed to project its own image. Visual research conducted at UKM confirmed this excess of design conformity in the design of some buildings on campus. Not only are these buildings uniform, they in fact share identical designs (Refer to Figure 5 and Figure 6). This similarity made it difficult to differentiate one building from another, with each building failing to project a unique image. The buildings also failed to indicate the diversity of the disciplinary areas that exist on campus.

\subsection{Landscape and surrounding}

Landscaping is one of the aspects that must be emphasized in campus planning. Rather than simply beautifying and brightening the campus area, landscaping plays multiple roles. Landscaping can adjust components of the campus microclimate (Zulkifli Hanafi 1999), set psychological boundaries that define a space, help 'wayfinding' and, most importantly, complement the architecture (Walker and McGough 1962). Therefore, the element of landscape is one of the most important components in creating a comfortable campus environment. This is consistent with the objective of a sustainable campus, which is emphasized in improving the quality of life.

Overall, the majority of the respondents from all campuses stated that the landscapes on their campuses are adequate and create a comfortable campus environment. However, UKM campus had the lowest percentage (48\%) compared to the other campus (Refer to Table 4). Research and visual observation conducted found that even though the UKM campus is surrounded by a green area, landscape design especially in residential and academic areas, is a lesser concern. The landscaping elements that have been applied are not designed based on themes or a unique concept. This affects the comfort of the campus environment. For other campus, the landscape design is more structured and well maintained, which creates a comfortable atmosphere on campus.

Meanwhile, a higher percentage of students agreed that landscape aided the learning process, with $60 \%$ and $63 \%$ on the USM and UPM campuses compared to $45 \%$ and $46 \%$ on the UKM and UM campuses, respectively (Refer to Table 4). The USM campus aims to create a 'university in the garden' to emphasize aspects of a comfortable learning environment. Trees on the USM campus cannot easily be cut down or thrown away, so the matured trees remain as campus heritage assets, which maintain a natural environment that provides peace and comfort to help students in the learning process. For UPM campus, although it is not very attractive, the landscapes look neat and well maintained, providing a pleasant visual experience and learning environment, which can impact the campus community and especially the students.

Research also found that landscape elements were manipulated as a tool to increase wayfinding on campuses. At USM, landscape elements are used to define the road hierarchy. Landscape design has been used on the USM campus to differentiate between the main roads and secondary roads. In addition, landscape design that used a consistent plant species along the main road (near the campus entrance) provided a sense of welcoming to visitors by showing the direction of travel.

However, research campuses still lack complex landscape elements, such as sculptures and decorations, that can be used as landmarks. Although the majority of responses from each campus reflect that there are some of these elements, a low positive response percentage was recorded (Refer to Table 4). These more complex landscaping elements, when present, are often in hard to reach locations and left in disrepair. This inattention may reduce the campus community's enjoyment of the campus environment and reduce the potential of the outdoor space as a medium for effective learning.

\subsection{Transport and movement}

Transportation is one of the most important aspects in life because people are always moving from one place to another. The purpose of movement is to obtain goods and travel to events and activities (Litman \& Laube 2002). The best way to improve transportation is to encourage walking and cycling while reducing vehicle travel 
(Litman 2010).

The results from conducted research show that all campuses provide bus services to ease the students' commute. On average, the respondents stated that the bus services are comfortable, except for on the UM campus (42\%). The responses are evenly split between approval and disapproval of the bus services overall (Refer to Table 5). In addition, the majority of respondents (except UM campus $-45 \%$ ) state that they usually use public services. There were complaints from the UM campus respondents about the public transporation services on their campus.

"The public transportation is sometimes not on schedule. The drivers take breaks earlier than their schedules indicate" - Respondent 47 from UM campus.

"To ensure that the bus driver complies with the rules, the drivers are expected to adopt the slogan 'courtesy of our culture'..."'- Respondent 18 from UM campus.

In addition, the majority of respondents state that they were comfortable using a private vehicle (Refer to Table 5). The highest percentage of student that used private vehicles as recorded at UPM campus (61\%). This may be due to superior road conditions on the UPM campus compared to other campuses. The separation of the circulation between academic and residential areas assists vehicle motion patterns and improves road safety, especially in residential areas. Furthermore, parking is not a serious problem on the UPM campus compared to other campus (Refer Table 5).

\subsection{Safety and lighting}

Academic communities should be equipped with convenient and secure access to all facilities for all users (Shuhana et al. 2007b). Based on the feedback received from the respondents, there are several locations that appear to be unsafe on the research campuses (Refer to Table 6). Roads, walkways and parking are among the areas that are considered to be the most risky. It was observed that lighting levels were lower in areas with less satisfaction with safety. Below are the most common complaints received from the respondents:

"There are few places outside the residential area where it is too dark. There are also certain roads on the hill where it is dark like a haunted house" - Respondents 17 from UM campus.

"Please increase the number of lights so that the residential area is brighter residential area and the residents feel safe." - Respondent 19 from USM campus.

"To increase number of street lights on Lebuh Silicon, which is the road to the entrance of UPM."- Respondent 12 from UPM campus.

"Ensure better security and lighting at pusanika and pedestrian walkways at night." - Respondent 37 from UKM campus.

Research has also found that automobile and pedestrian circulation design is less sensitive to security needs. Dark walkways with no segregation between pedestrian walkways and roads exist for long stretches. This far distance must be travelled at high risk, and the pedestrians and other road users feel unsafe. Street light usage is unsatisfactory and obscures the vision of drivers. Moreover, the road conditions are poorly maintained, which increases the risk of accidents. Below are the complaints received from the respondents:

"Add the lights on campus in the dark and lonely areas that make students feel unsafe, especially when coming back from night classes." - Respondent 25 from USM campus.

"Change to brighter lights that do not obstruct the view of those who use the roads." - Respondent 41 from UKM campus.

"Repair the damaged road for safety reasons." - Respondent 28 from UPM campus.

Dark and insecure parking areas scare the students. The incidence of crime, especially theft of motorcycles, demonstrates the informal security atmosphere in the design of the parking area. One of the comments received was the following:

"Provide secure motorcycle parking lot at College Amin. Motorcycles are always stolen at the end of the semester" - Respondent 65 from UKM campus.

Complaints and comments received indicate the importance of safety and lighting on campus. Both of these aspects are less emphasized during the planning and design of research campuses. The main cause of this problem is the placement and layout of buildings. As a result, the provision of secure areas, clearly lit roadways and optimum lighting are difficult to obtain.

\section{Conclusion}

The establishment of a sustainable campus is very important. A sustainable campus provides a better environment for the campus community, especially for students in terms of their environmental, social and economic quality of life. The physical development planning of a campus has a great impact on student life and affects their decision making. These findings prove that the best way to create a sustainable campus is by developing a compact campus. Among the four campuses, USM campus is the most compact campus. The 
comparative results from the questionnaire show that the fewest problems occur on the USM campus. There is distinct evidence that supports the idea that a compact campus can be more satisfactory by increasing accessibility; providing more efficient circulation and transportation systems; and increasing the level of security and lighting. In contrast, a dispersed campus contradicts the goal of sustainability. The results of this study support the findings of previous researchers, such as Burton (2000) and Burns (2001).

In conclusion, the physical development planning of a campus plays an important role in enhancing the sustainability of that campus. To ensure that a sustainable campus is successfully established, a compact physical development plan is encouraged.

\section{References}

Abdul Ghani Abdullah, Aziah Ismail. (2007). Kesediaan Memperkasa Pendidikan Pembangunan Lestari Oleh Pengurus Pendidikan Sekolah: Satu Kajian Kes. Universiti Sains Malaysia.

Aldrin Abdullah, Lee Lik Meng, Lim Yoke Mui, Nurwati Badarulzaman \& Azizi Bahauddin. (2006). Pedestrian Network And Landscape Design Proposal. The University In A Garden. USM, Pulau Pinang.

Beatley, T. (2003). Planning for sustainability in European cities: A review of practices in leading cities. The Sustainable Urban Development Reader. Edited by Wheeler, S. M. and Beatley, T. 2004. London: Routledge.

Beringer, A., Wright, T. \& Malone, L. (2008). Sustainability In Higher Education In Atlantic Canada. International Journal of Sustainability in Higher Education. Vol. 9, No. 1, pp. 48-67.

Brundtland Report (1987). Our Common Future: The World Commission for the Environment and Development. Madrid: Alianza Publication.

Burns, R. (2001). Designing the university campus: It matters. National Forum. Summer 2001.

Burton, E. (2000). The Compact City: Just or Just Compact? A Preliminary Analysis. Urban Studies. Vol. 37 , No. 11. pp. 1969-2006.

Campos, P. (2008). Sustainable Education Campus in Spain: Nature and Architecture for Training. Organisation For Economic Co-Operationand Development.

Chua Yan Piaw. 2006. Kaedah Penyelidikan. McGraw-Hill (Malaysia) Sdn. Bhd. Malaysia.

D'amico L. A. \& Brooks, W. D. (1968). The Spatial Campus. A Planning Scheme and Annotated Bibliography.

Dahle, M. \& Neumayer, E. (2001). Overcoming Barriers to Campus Greening: A Survey among Higher Educational Institutions in London, UK. International Journal of Sustainability in Higher Education. Vol 2 No 2. pp. $139-160$.

Davis, G. \& Wolski, M. (2009). E-Waste And The Sustainable Organisation: Griffith University's Approach To E-Waste. International Journal of Sustainability in Higher Education. Vol. 10, No. 1, pp. 21-32.

De Vaus, D. (2002). Sample size. Surveys in Social Research. $5^{\text {th }}$ edition. Routledge. London.

Dober, R. 1963. Campus Planning. Society of College and University Planning. Ann Arbor, MI USA.

Farrell, A. and Hart, M. (1998). What Does Sustainability Really Mean? The Search for Useful Indicators. Environment 40 (9): 4-9, 26-31.

Drumheller, B., Quaid, A., Wyman, M., Liljenwall, J. \& Young, A. (2001). Sustainable Transportation Options For Protecting The Climate. A Guide For Local Governments. International Council for Local Environmental Initiatives. USA.

Ferrer-Balas, D., Adachi, J., Banas, S., Davidson, C. I., Hoshikoshi, A., Mishra, A., Motodoa, Y., Onga, M. \& Ostwald, M. (2008). An International Comparative Analysis Of Sustainability Transformation Across Seven Universities. International Journal of Sustainability in Higher Education. Vol. 9, No. 3, pp. 295-316.

Franklin, C., Durkin, T. \& Schuh, S. P. (2003). The role of the landscape in creating a sustainable campus. Planning for Higher Education. Mac-May 2003.

Hoinville, G., Jowell. R., et al. (1977). Survey Research Practice. Heinemann. London.

Isiaka, A. \& Ho Chin Siong. (2008). Developing Sustainable Index For University Campus. EASTS International Symposium on Sustainable Transportation incorporating Malaysian Universities Transport Research Forum Conference 2008 (MUTRFC08). Universiti Teknologi Malaysia. 12-13 August 2008.

Jain, S., \& Pant, P. (2010). Environmental Management Systems For Educational Institutions. A Case Study Of TERI University, New Delhi. International Journal of Sustainability in Higher Education. Vol. 11, No. 3, pp. 236-249.

Lele, S. (1991). Sustainable Development" A Critical Review. World Development, Vol. 19, No. 6, pp. $607-621$. Pergamon Press. Great Britain.

Litman, T. (2008). Measuring Transportation: Traffic, Mobility and Accessibility. Victoria Transport Policy Institute. Victoria. 4 November 2008; at http://www.vtpi.org/measure.pdf. 
Litman, T. A. (2010). Economic Value of Walkability. Victoria Transport Policy Institute. Victoria; at http://www.vtpi.org/walkability.pdf

Litman, T. \& Laube, F. (2002). Automobile Dependency and Economic Development. Victoria Transport Policy Institute. Victoria, Canada.

Mohd Tajuddin Mohd Rasdi. (2003). Campus Design in Malaysia: of Motorcycles and Mediocrity. Crisis in Public Architecture. KALAM. Universiti Teknologi Malaysia. pp. 1-8.

Nicolaides, A. (2006). The Implementation Of Environmental Management Towards Sustainable Universities And Education For Sustainable Development As An Ethical Imperative. International Journal of Sustainability in Higher Education. Vol. 7, No. 4, pp. 414-424.

Norton, R. K., Brix, A., Brydon, T., Davidian, E., Dinse, K., dan Vidyarthi, S. (2007). Transforming The University Campus Into Sustainable Community. Planning for Higher Education. Vol 35, No 4 pp 22-39.

Nurwati Badarulzaman, Lim Yoke Mui, Yeong Siew Yan, Lee Lik Meng \& Aldrin Abdullah. (2006). The University In A Garden. Participatory Planning Process. Healthy Campus Series (No. 16). Penerbit Universiti Sains Malaysia. Pulau Pinang.

Shuhana Shamsuddin, Ahmad Bashri Sulaiman, Hasanuddin Lamit, Rozeyta Omar, Norsiah Abd. Aziz, Masliyana Md. Noor. (2007). Kompendium Perancangan Dan Reka Bentuk Kampus Kondusif. Skudai: Penerbit Universiti Teknologi Malaysia.

Shuhana Shamsuddin, Ahmad Bashri Sulaiman, Hasanuddin Lamit, Rozeyta Omar, Norsiah Abd. Aziz, Masliyana Md. Noor. (2007). Kriteria Reka Bentuk Persekitaran Kampus Yang Kondusif Bagi Institusi Pengajian Tinggi Di Malaysia. University Teknologi Malaysia.

Sohif Mat, Kamaruzzaman Sopian, Mazlin Mokhtar, Baharuddin Ali, Halimaton Saadiah Hashim, Abdul Khalim Abdul Rashid, Muhammad Fauzi Mohd Zain dan Nurakmal Goh Abdullah. (2009). Managing Sustainable Campus in Malaysia - Organisational Approach and Measures. European Journal of Social Sciene. Volume 8, Number 2, pp 201-214.

Sulong Mohamad. (1983). Perancangan Kemudahan Awam Dan Infrastruktur Sosial: Konsep,Prinsip Dan Amalan. Bangi: Penerbit Universiti Kebangsaan Malaysia.

University of Victoria Campus Planning Committee. (2005). University of Victoria Campus Design Guidelines. Campus Planning and Sustainability. University of Victoria.

Walker \& McGough. (1962). University of Washington Campus Planning. Analysis and Guide.

Wheeler, S. M. 2002. "Infill development" from Smart Infill: Creating More Livable Communities in the Bay Area. The Sustainable Urban Development Reader. Edited by Wheeler, S. M. and Beatley, T. 2004. London: Routledge.

Zulkifli Hanafi. (1999). Reka Bentuk Bangunan Dalam Iklim Panas Dan Lembab Di Malaysia. Kuala Lumpur: Dewan Bahasa Dan Pustaka.

Table 1. Respondents' feedback on the accessibility between the residential and functional areas on campus

\begin{tabular}{|l|l|l|l|l|l|l|l|l|l|l|l|l|}
\hline \multirow{2}{*}{$\begin{array}{l}\text { Area/building } \\
\text { on campus. }\end{array}$} & \multicolumn{1}{c|}{ PERCENTAGE BY CAMPUS } \\
\cline { 2 - 15 } & \multicolumn{4}{|c|}{ UKM } & \multicolumn{3}{c|}{ USM } & \multicolumn{3}{c|}{ UM } & \multicolumn{3}{c|}{ UPM } \\
\cline { 2 - 13 } & $\mathrm{Y}$ & NS & N & Y & NS & N & Y & NS & N & Y & NS & N \\
\hline Academic buildings & 50 & 8 & 42 & 65 & 9 & 26 & 59 & 5 & 36 & 63 & 17 & 20 \\
Facilities areas & 61 & 8 & 31 & 48 & 18 & 34 & 39 & 13 & 48 & 53 & 20 & 27 \\
Recreational areas & 34 & 16 & 50 & 62 & 16 & 22 & 51 & 9 & 40 & 62 & 13 & 25 \\
\hline
\end{tabular}

$\mathrm{Y}=$ Yes, $\mathrm{NS}=$ Not sure, $\mathrm{N}=$ No

Table 2. Respondents' feedback about circulation systems on campus

\begin{tabular}{|l|l|l|l|l|l|l|l|l|l|l|l|l|}
\hline \multirow{3}{*}{ Circulation areas on campus } & \multicolumn{1}{|c|}{ PERCENTAGE BY CAMPUS } \\
\cline { 2 - 14 } & \multicolumn{3}{|c|}{ UKM } & \multicolumn{3}{c|}{ USM } & \multicolumn{3}{c|}{ UM } & \multicolumn{3}{c|}{ UPM } \\
\cline { 2 - 13 } & Y & NS & N & Y & NS & N & Y & NS & N & Y & NS & N \\
\hline Covered walkways & 18 & 32 & 50 & 23 & 13 & 64 & 24 & 14 & 62 & 24 & 24 & 52 \\
Pedestrian amenities & 29 & 33 & 38 & 44 & 22 & 34 & 48 & 17 & 35 & 49 & 24 & 27 \\
Bicycle paths & 23 & 25 & 52 & 18 & 20 & 62 & 13 & 21 & 66 & 45 & 27 & 28 \\
\hline
\end{tabular}

$\mathrm{Y}=$ Yes, $\mathrm{NS}=$ Not sure, $\mathrm{N}=$ No 
Table 3. Respondents' feedback about the uniqueness of the building designs on campus

\begin{tabular}{|c|c|c|c|c|c|c|c|c|c|c|c|c|}
\hline \multirow{3}{*}{$\begin{array}{l}\text { Area/building } \\
\text { on campus. }\end{array}$} & \multicolumn{12}{|c|}{ PERCENTAGE BY CAMPUS } \\
\hline & \multicolumn{3}{|c|}{ UKM } & \multicolumn{3}{|c|}{ USM } & \multicolumn{3}{|c|}{ UM } & \multicolumn{3}{|c|}{ UPM } \\
\hline & $\mathrm{Y}$ & NS & $\mathrm{N}$ & $\mathrm{Y}$ & NS & $\mathrm{N}$ & $\mathrm{Y}$ & NS & $\mathrm{N}$ & $\mathrm{Y}$ & NS & $\mathrm{N}$ \\
\hline Residential & 32 & 34 & 34 & 47 & 31 & 22 & 56 & 28 & 13 & 48 & 28 & 24 \\
\hline Academic & 46 & 26 & 28 & 54 & 26 & 20 & 67 & 21 & 12 & 68 & 24 & 8 \\
\hline Facilities & 37 & 43 & 20 & 50 & 39 & 11 & 56 & 40 & 4 & 61 & 31 & 8 \\
\hline
\end{tabular}

$\mathrm{Y}=$ Yes, $\mathrm{NS}=$ Not sure, $\mathrm{N}=$ No

Table 4. Respondents' feedback about the landscape on campus

\begin{tabular}{|c|c|c|c|c|c|c|c|c|c|c|c|c|}
\hline \multirow{3}{*}{$\begin{array}{l}\text { Area/building } \\
\text { on campus. }\end{array}$} & \multicolumn{12}{|c|}{ PERCENTAGE BY CAMPUS } \\
\hline & \multicolumn{3}{|c|}{ UKM } & \multicolumn{3}{|c|}{ USM } & \multicolumn{3}{|c|}{$\overline{\mathrm{UM}}$} & \multicolumn{3}{|c|}{ UPM } \\
\hline & $\mathrm{Y}$ & NS & $\mathrm{N}$ & $\mathrm{Y}$ & NS & $\mathrm{N}$ & $\mathrm{Y}$ & NS & $\mathrm{N}$ & $\mathrm{Y}$ & NS & $\mathrm{N}$ \\
\hline Comfortable and adequate & 48 & 29 & 23 & 71 & 18 & 11 & 61 & 25 & 14 & 65 & 23 & 12 \\
\hline Support education & 45 & 37 & 18 & 60 & 27 & 13 & 46 & 38 & 16 & 63 & 26 & 11 \\
\hline Usable hardscape & 50 & 27 & 23 & 50 & 34 & 16 & 47 & 49 & 14 & 55 & 32 & 13 \\
\hline
\end{tabular}

$\mathrm{Y}=$ Yes, $\mathrm{NS}=$ Not sure, $\mathrm{N}=$ No

Table 5. Respondents' feedback about the transportation systems on campus

\begin{tabular}{|l|l|l|l|l|l|l|l|l|l|l|l|l|}
\hline \multirow{2}{*}{$\begin{array}{l}\text { Area/building } \\
\text { on campus. }\end{array}$} & \multicolumn{10}{|c|}{ PERCENTAGE BY CAMPUS } \\
\cline { 2 - 14 } & \multicolumn{4}{|c|}{ UKM } & \multicolumn{3}{|c|}{ USM } & \multicolumn{3}{c|}{ UM } & \multicolumn{3}{c|}{ UPM } \\
\cline { 2 - 13 } & Y & NS & N & Y & NS & N & Y & NS & N & Y & NS & N \\
\hline Convenience of public transport & 49 & 25 & 26 & 56 & 14 & 30 & 42 & 16 & 42 & 60 & 18 & 22 \\
Regular use of public transport & 52 & 14 & 34 & 64 & 3 & 33 & 45 & 9 & 46 & 62 & 14 & 24 \\
Convenience with private vehicles & 52 & 27 & 21 & 56 & 24 & 20 & 46 & 28 & 26 & 61 & 25 & 14 \\
Adequate \& convenient parking & 18 & 22 & 60 & 26 & 20 & 54 & 16 & 27 & 57 & 32 & 27 & 41 \\
\hline
\end{tabular}

$\mathrm{Y}=$ Yes, NS = Not sure, $\mathrm{N}=$ No

Table 6. Respondents' feedback about security and lighting levels on campus

\begin{tabular}{|c|c|c|c|c|c|c|c|c|c|c|c|c|}
\hline \multirow{3}{*}{$\begin{array}{l}\text { Area/building } \\
\text { in campus. }\end{array}$} & \multicolumn{12}{|c|}{ PERCENTAGE BY CAMPUS } \\
\hline & \multicolumn{3}{|c|}{ UKM } & \multicolumn{3}{|c|}{ USM } & \multicolumn{3}{|c|}{ UM } & \multicolumn{3}{|c|}{ UPM } \\
\hline & $\mathrm{Y}$ & NS & $\mathrm{N}$ & $\mathrm{Y}$ & NS & $\mathrm{N}$ & $\mathrm{Y}$ & NS & $\mathrm{N}$ & $\mathrm{Y}$ & NS & $\mathrm{N}$ \\
\hline Security: & & & & & & & & & & & & \\
\hline Residential & 36 & 24 & 40 & 65 & 14 & 21 & 57 & 18 & 25 & 58 & 23 & 19 \\
\hline Academic & 41 & 29 & 30 & 55 & 21 & 24 & 57 & 24 & 18 & 67 & 21 & 12 \\
\hline Facilities & 36 & 31 & 33 & 46 & 30 & 24 & 53 & 27 & 20 & 55 & 37 & 8 \\
\hline Roads & 36 & 33 & 31 & 48 & 14 & 38 & 45 & 26 & 29 & 48 & 34 & 18 \\
\hline Parking areas & 31 & 28 & 41 & 36 & 24 & 40 & 46 & 30 & 34 & 46 & 42 & 22 \\
\hline Walkways & 29 & 38 & 33 & 39 & 17 & 44 & 37 & 26 & 67 & 44 & 36 & 20 \\
\hline Lighting: & & & & & & & & & & & & \\
\hline Residential & 44 & 30 & 26 & 73 & 17 & 10 & 58 & 17 & 25 & 65 & 14 & 21 \\
\hline Academic & 40 & 25 & 35 & 53 & 24 & 23 & 53 & 27 & 20 & 62 & 22 & 16 \\
\hline Facilities & 45 & 21 & 34 & 51 & 28 & 21 & 48 & 31 & 21 & 46 & 31 & 23 \\
\hline Roads & 34 & 23 & 43 & 55 & 22 & 23 & 49 & 24 & 27 & 51 & 25 & 24 \\
\hline Parking areas & 32 & 20 & 48 & 37 & 16 & 47 & 37 & 28 & 35 & 35 & 25 & 40 \\
\hline Walkways & 22 & 26 & 52 & 28 & 23 & 49 & 33 & 23 & 44 & 32 & 31 & 37 \\
\hline
\end{tabular}

$\mathrm{Y}=$ Yes, $\mathrm{NS}=$ Not sure, $\mathrm{N}=$ No 


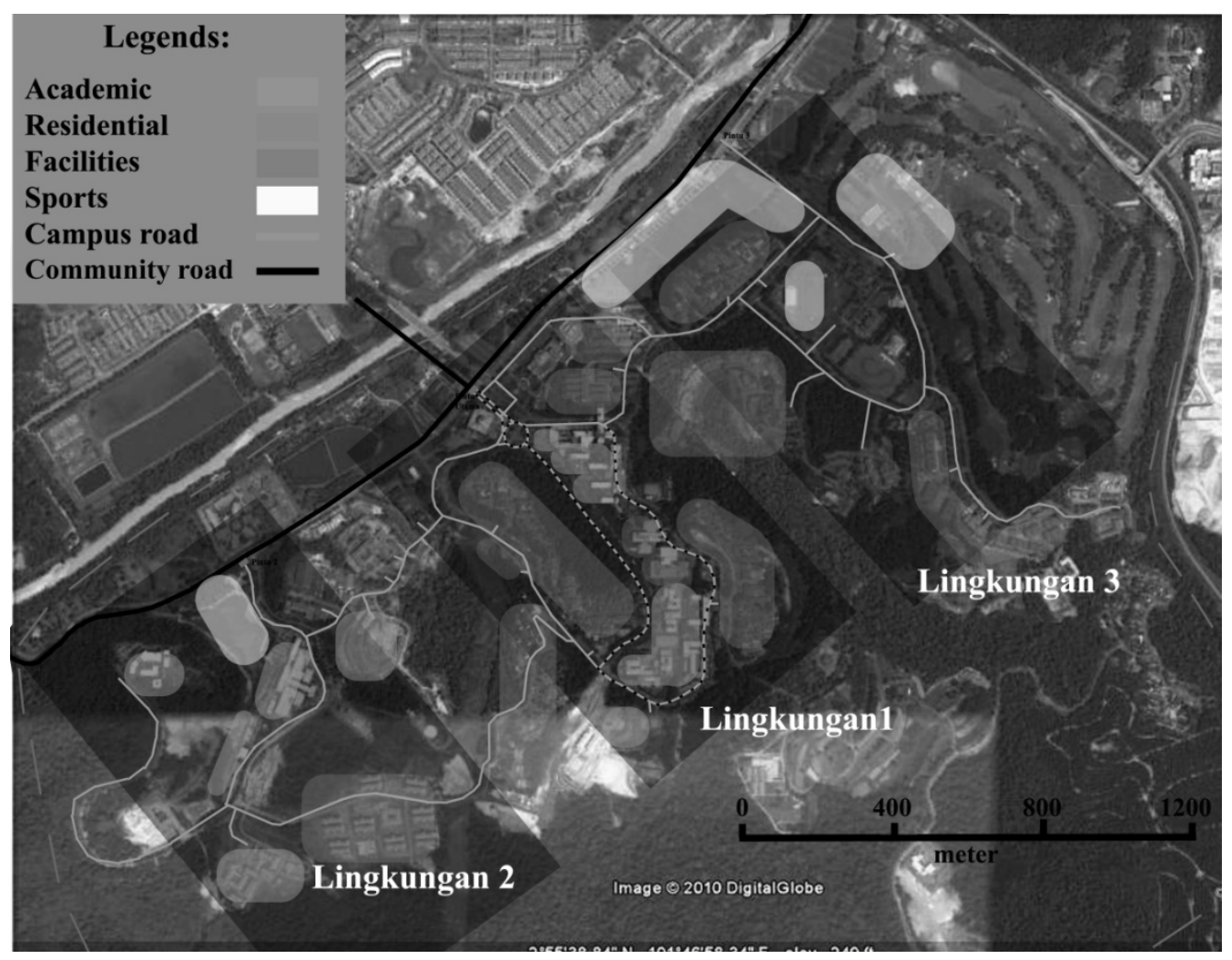

Figure 1. UKM campus layout

(Source: Google Earth. Edited by the author - not to scale)

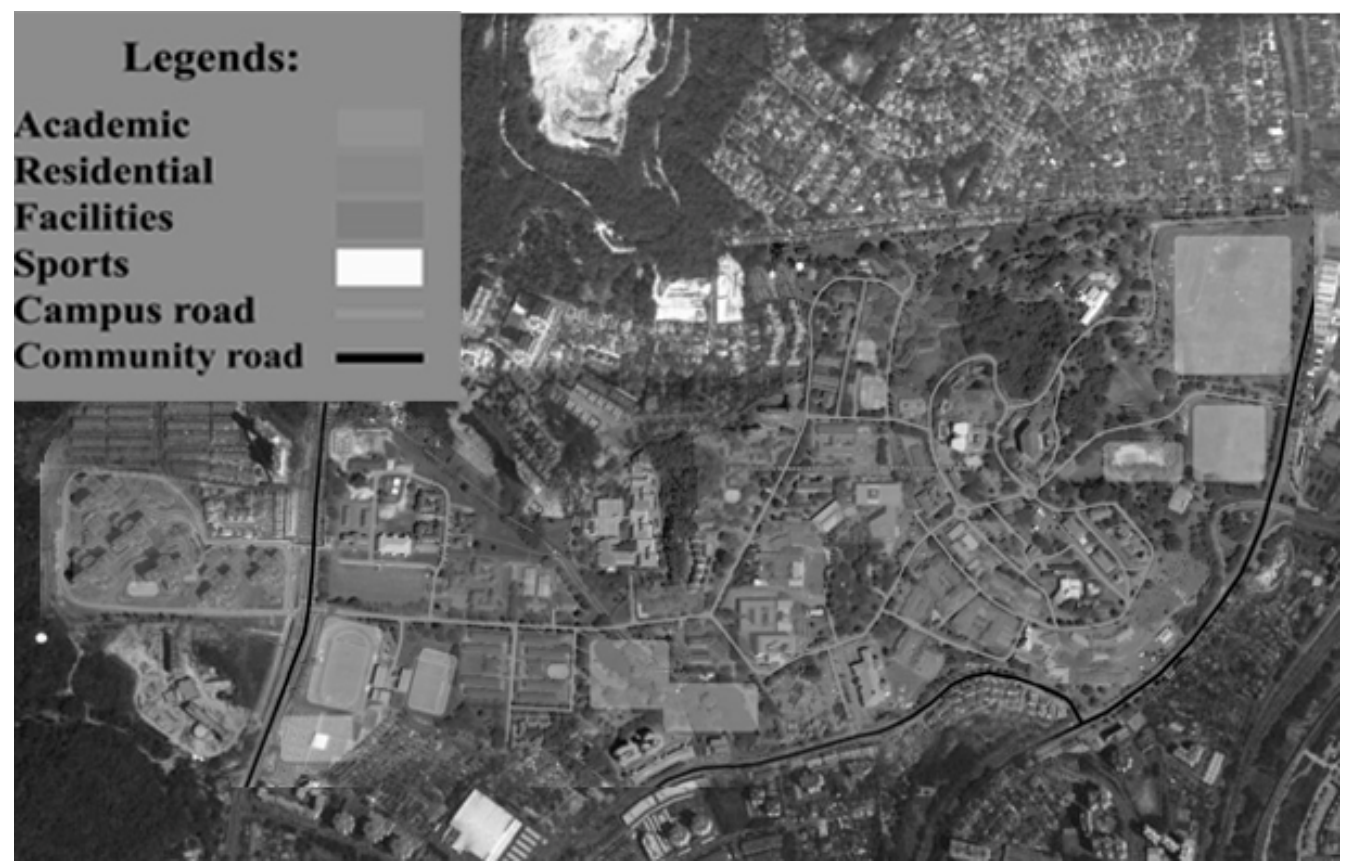

Figure 2. USM campus layout

(Source: Google Earth. Edited by the author - not to scale) 


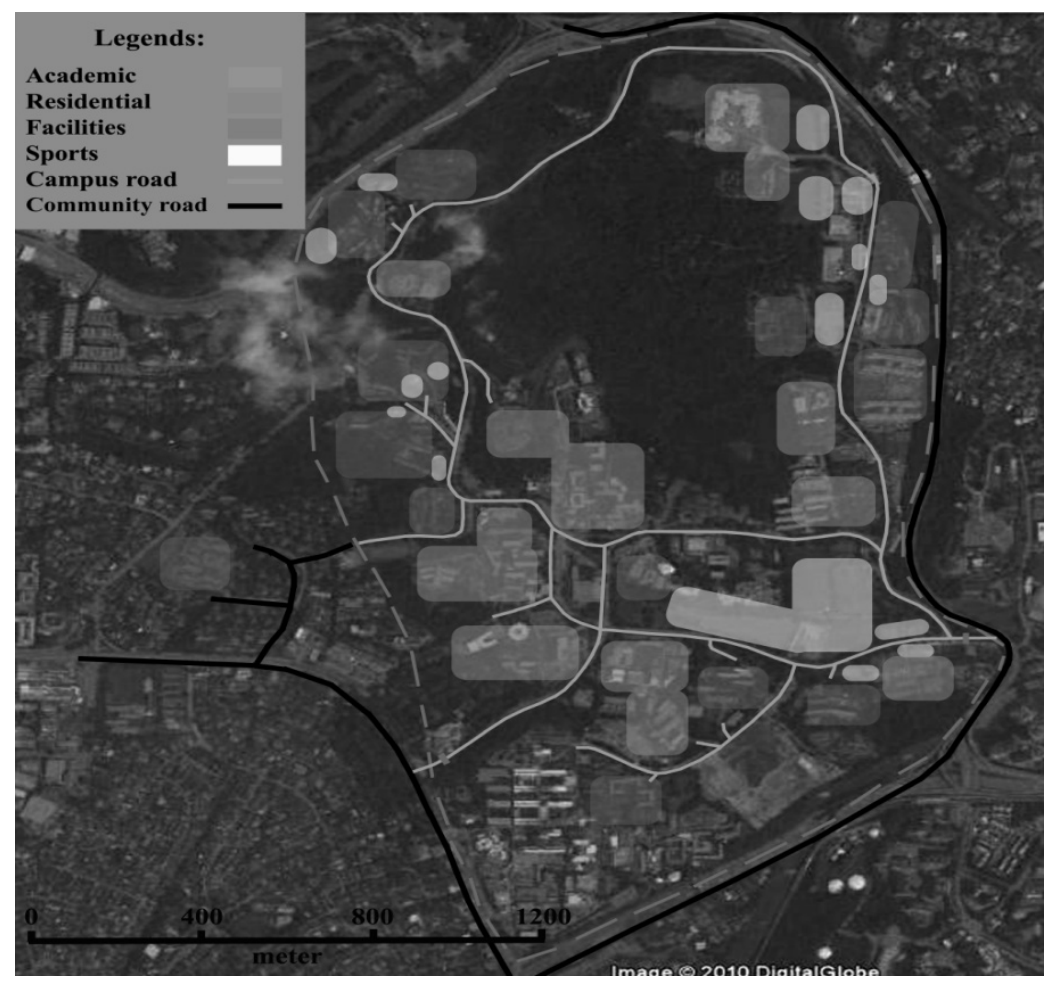

Figure 3. UM campus layout

(Source: Google Earth. Edited by the author - not to scale)

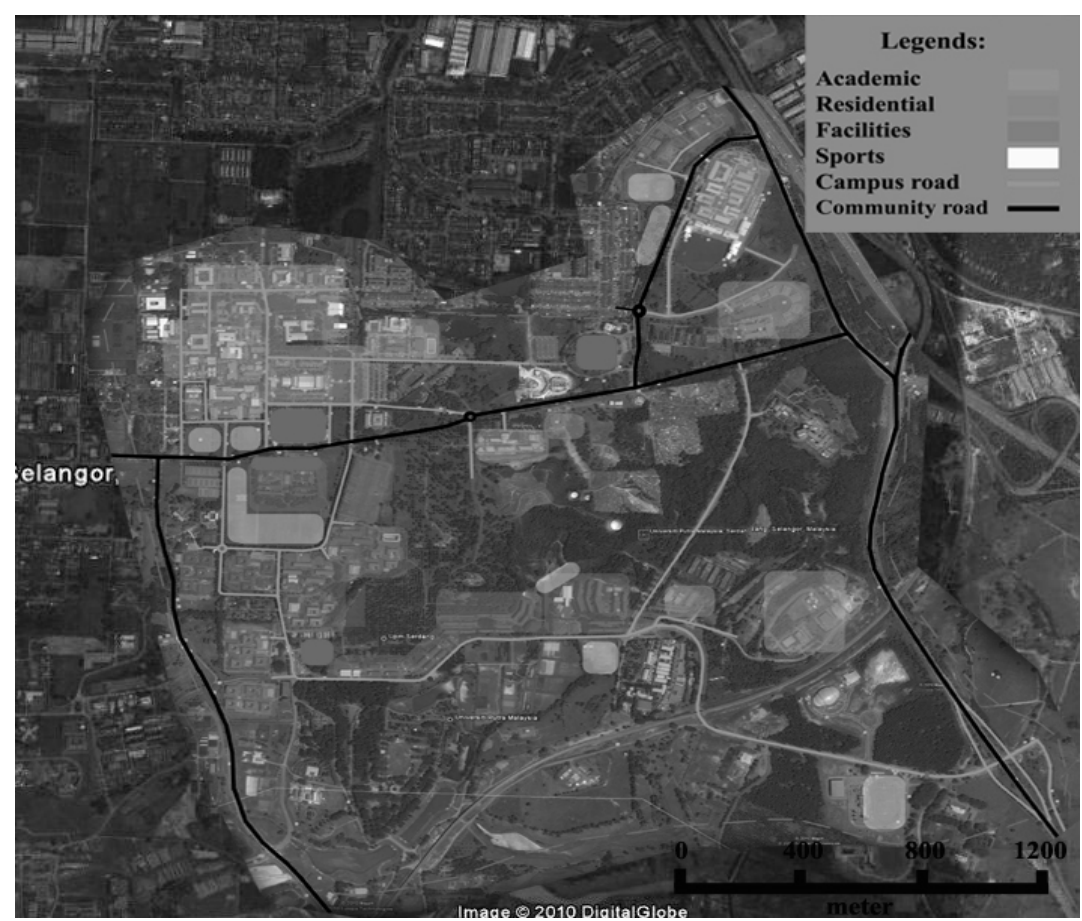

Figure 4. UPM campus layout

(Source: Google Earth. Edited by the author - not to scale) 

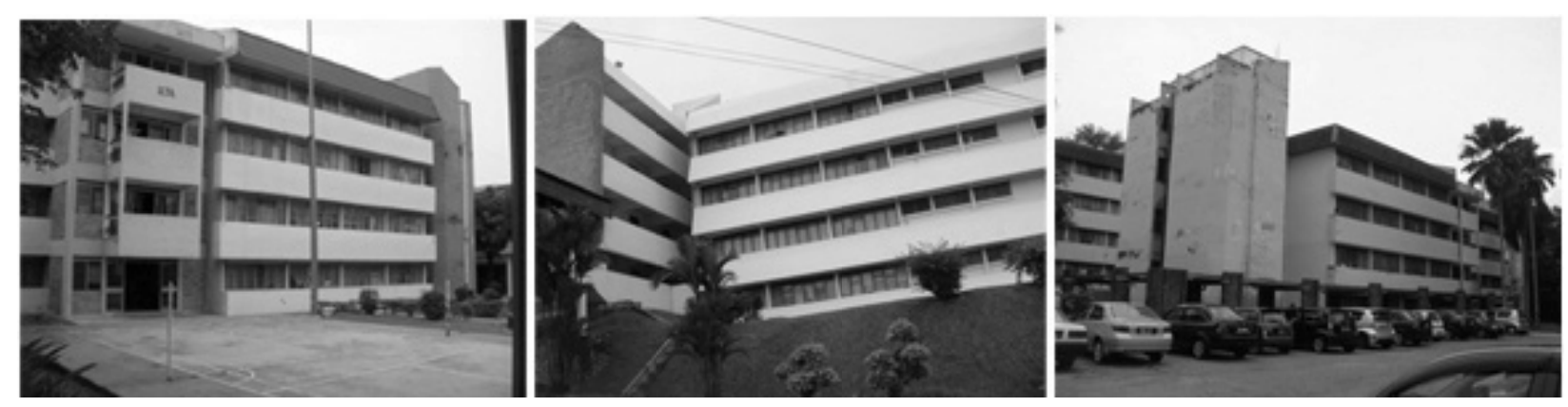

Figure 5. Photograph of different residential colleges on UKM campus that have similar designs
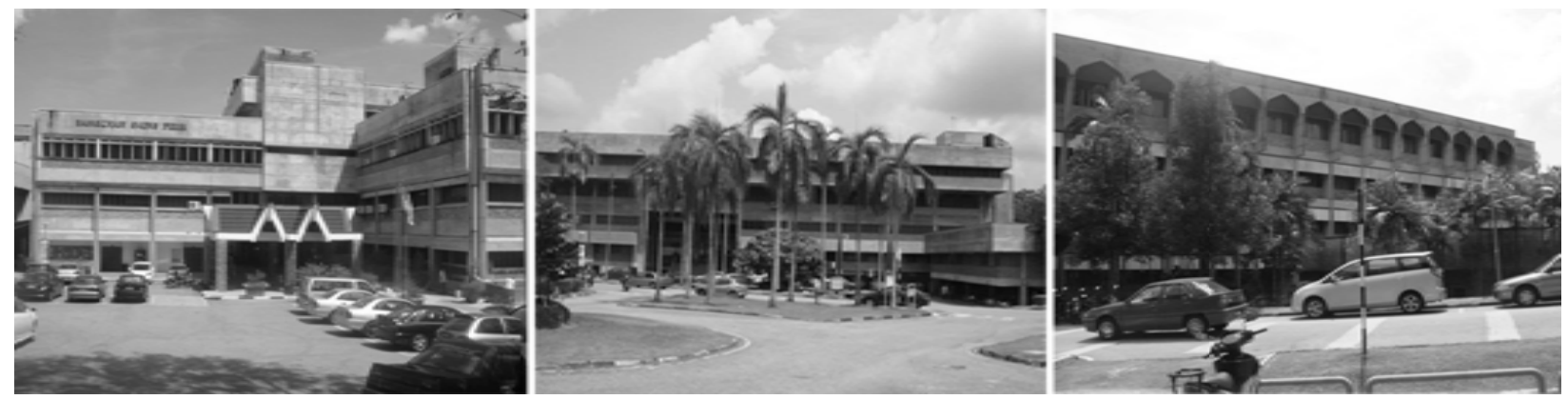

Figure 6. Photograph of different buildings on the UKM campus that have similar designs 